\begin{tabular}{l}
\hline Jurnal Pakarena \\
Volume 3 Nomor 2, Desember 2018 \\
p-ISSN: $1693-3990$ \\
$\begin{array}{ll}\text { (c) (1) This work is licensed under a Creative Commons Attribution } \\
\text { 4.0 International License }\end{array}$ \\
\hline
\end{tabular}

\title{
MAKNA SIMBOLIK TARI PABITTE PASSAPU PADA UPACARA PERNIKAHAN DI KECAMATAN KAJANG
}

Rahma M
Keywords :
Makna simbolik; Tari
Pabitte Passapu
Corespondensi Author
Pendidikan Sendratasik Fakultas
Seni dan Desain Universitas
Negeri Makassar
rahma.m@unm.ac.id

\begin{abstract}
ABSTRAK
Makna dalam gerak tari tentu saja tidak bisa disamakan dengan memaknai sebuah kata atau bahasa dimana hampir semua kata dapat dijelaskan artinya seperti gerak yang terdapat didalam kamus, walaupun ada beberapa bentuk seni gerak yang dapat dimaknai setiap gerak yang dilakukan misalnya pantomim, namun gerak dalam tari tidaklah demikian sebab makna yang terkandung didalamnya biasanya berkaitan dengan filosofi atau falsafah hidup suatu masyarakat atau untuk kebutuhan tertentu. Seperti halnya masyarakat Sulawesi Selatan yang terdiri dari ratusan suku dan etnis tentu saja memiliki budaya dan bentuk seni yang berbeda-beda dan sarat akan makna yang berkaitan langsung dengan kehidupan masyarakatnya. Salah satu diantaranya adalah Tari Pabitte passapu pada upacara pernikahan di masyarakat kecamatan Kajang di Kabupaten Bulukumba.
\end{abstract}

\begin{abstract}
The meaning of dance movements certainly cannot be equated with the meaning of a word or language in which almost all words can be explained as meaning in the motion contained in a dictionary, although there are several forms of motion art that can be interpreted every movement made for example pantomime, but the motion in dance is not because the meaning contained therein is usually related to the philosophy or philosophy of life of a society or for certain needs. Like the people of South Sulawesi, which consists of hundreds of tribes and ethnicities, of course, have different cultural and artistic forms and are full of meaning that is directly related to the lives of the people. One of them is Pabitte Passapu Dance at a wedding ceremony in the Kajang sub-district community in Bulukumba Regency.
\end{abstract}

\section{PENDAHULUAN}

Makna gerak dalam tari terletak dalam penjiwaannya, hal ini dapat dipahami sebagai suatu daya yang membuat makna itu ",hidup". Penjiwaan tidaklah harus seperti gambaran cerita melainkan hanya dalam rasa geraknya, yaitu penyaluran rasa melalui gerak itu sendiri. Gerak tersebut melibatkan ruang (bentuk dan volume geraknya), waktu (cepat lambat dan iramanya) beserta energy atau tenaga yang digunakan, jika pengaturan tersebut tepat, gerak tari tersebut akan dirasakan enak atau pas, baik oleh penari ataupun oleh penontonnya. Misalnya jika ayunan tangan, angkatan kaki, putaran tubuh, bisa terjiwai dengan baik, maka gerak tari tersebut akan terasa menjadi bermakna. (Sumaryono 2006:17)

Memberikan wujud terhadap apa yang kita lihat, rasakan, tangkap dan pahami secara imajinatif adalah kebutuhan terus menerus dari manusia. Suatu dorongan dari dalam mendesak kita untuk menyusun elemen-elemen khusus pengalaman kita menjadi sesuatu yang bermakna, menata sesuatu yang tidak tertata, dan menciptakan 
Rahma M, Makna Simbolik Tari Pabitte Passapu Pada Upacara Pernikahan Di Kecamatan Kajang.

bentuk dari kesemrawutan. Kecenderungan seperti itu dapat kita lihat dari kehidupan sehari-hari. Demikian pula halnya dengan apa yang kita lihat dan temukan dari harikehari. Kita dipaksa untuk menggabungkan berbagai pengalaman sehingga semuanya menjadi masuk akal dan memperjelas hubungan kita dengan dunia sekitar. Pencarian kedalam batin bagi keteraturan ini menghasilkan sebuah proses yang kita kenal dengan istilah simbolis. Proses simbolis itu sendiri memberikan kepuasan, dan dalam kaitan yang lebih luas memenuhi kebutuhan manusia yang paling mendasar. Kebutuhan untuk memberikan wujud terhadap pengalaman kita, yang kemudian dapat dijadikan sarana untuk mengetahui, berekspresi dan berkomunikasi.

Masyarakat kawasan Tana Toa memiliki dua jenis ritual, yakni ritual Duka cita dan Ritual Suka cita. Dan, pada setiap ritual memiliki media yang berbeda dalam menyampaikan permohonan mereka Pada $T u$ Rie A'ra'na (Tuhan Yang Maha Kuasa). Media yang digunakan selain sebagai sarana penyampaian hasrat juga merupakan pelampiasan atau penyaluran dari ekspresi dan perasaan mereka terhadap sesuatu. Misalnya jika sedang berduka cita karena kematian sanak keluarga biasanya ekspresi duka mereka tercurah dalam alunan seruling yang bagi masyarakat kawasan disebut dengan basing atau seruling kedukaan, irama seruling yang yang diiringi vocal (royong) yang menyayat merupakan penggambaran rasa sakit mereka ditinggal oleh sanak keluarga yang meninggal dunia, dan basing ini menjadi salah satu bagian penting dalam ritual kematian pada masyarakat kawasan Tana Toa. Selain ritual duka cita, ritual suka citapun tidak lepas dari media sebagai sarana meluapkan perasaan mereka, yakni Ngaru dan Pabbate Passapu.

Pabbatte Passapu merupakan salah satu tari yang berkembang dalam kawasan, selain tari Annete Panne Pada ritual Attahuru' Bente yang sering dilakukan oleh masyarakat kawasan. Tari ini merupakan penggambaran kebiasaan kaum laki-laki kawasan Tana Toa dalam mengisi waktu lowong sehabis melakukan aktivitas mereka. Tari ini terinspirasi dari kebiasaan laki-laki dalam kawasan menyabung ayam, kemudian setelah islam masuk kebiasaan menyabung ayam sudah dilarang, namun karena sudah terbiasa dengan aktivitas tersebut terlebih ketika ada acara-acara yang sifatnya suka cita atau kegembiraan, rasanya kurang lengkap jika tidak menyabung ayam sebagai hiburan. Sejak ada larangan menyabung ayam, maka ayampun diganti dengan menggunakan kain pengikat kepala mereka, mengingat ayam petarung sama pentingnya dengan harga diri maka penggantinya juga sesuatu yang memiliki posisi penting dalam pertaruhan harga diri mereka, yakni ikat kepala. Dan barang siapa yang pengikat kepalanya menyentuh tanah terlebih jika terjatuh maka dinyatakan kalah.

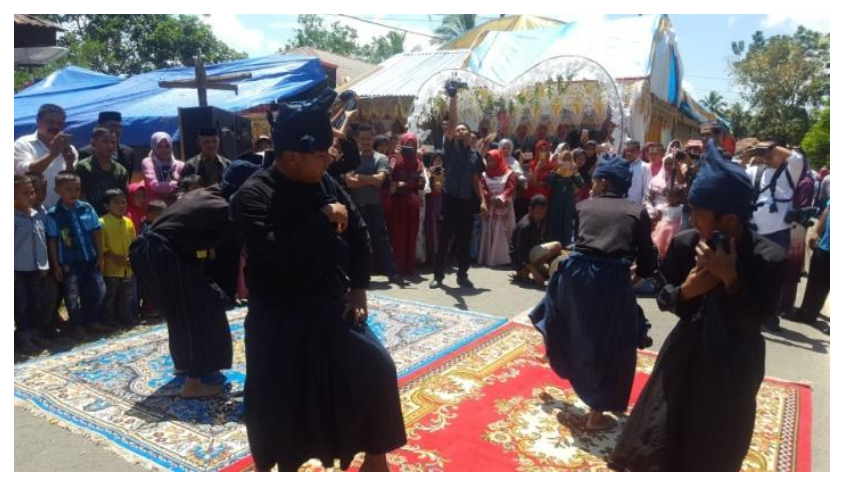

Gbr. 1. Salah satu ragam tari pabitte passapu pada upacara pernikahan di kec. Kajang, Dok. Rahma, 2018

\section{METODE PENELITIAN}

\section{Jenis Penelitian}

Sebagai penelitian kualitatif, sumber data yang digunakan yaitu: sumber tertulis, lisan, dan dokumentasi. Sumber data pada penelitian Makna Simbolik Tari Pabatte Pada Pesta Pernikahan Masyarakat Kajang ini menggunakan pendekatan dengan multi disiplin, yakni pendekatan psikologis, sosiologis, dan antropologis. Pendekatan multi disiplin bukan hanya terbatas pada 
analisisnya, akan tetapi juga pada pencarian dan pengumpulan datanya.

Untuk melengkapi data penelitian diperlukan sumber data dengan metode: 1). Studi pustaka yang bertujuan untuk mencari data akurat tentang objek penelitian dan mencari konsep-konsep teori yang dapat digunakan untuk membahas permasalahan melalui seleksi tulisan atau buku-buku yang mendukung objek penelitian, 2). Observasi untuk memperoleh data melalui penjajakan objek penelitian, dan observasi pada penelitian ini dilakukan dengan mengunjungi rumah masyarakat Kajang yang sedang menggelar upacar pernikahan anggota keluarganya, 3). Wawancara untuk mendapatkan data yang aotentik dan kredibel. Wawancara bukan hanya dilakukan dengan objek penelitian melainkan dengan informan dan narasumber yang lain, adapun responden dalam penelitian ini adalah pelaku tari, budayawan Desa Tana Toa Kajang, pemangku adat, dan orang tua dari mempelai perempuan, 4). Dokumentasi, yaitu melakukan kaji dokumen berupa buku catatan harian jika ada, agenda kegiatan dan ataupun photo yang buat sendiri ataupun dokumentasi, dokumentasi penelitian ini berupa catatan harian selama melakukan penelitian, dan foto-foto yang di peroleh dilokasi (pengambilan gambar dilakukan oleh tim peneliti sendiri).

\section{Variable}

Berdasarkan tujuan penalitian yang akan dicapai, maka dikemukakan beberapa variable tentang Makna Simbolik Tari Pabatte Passapu Dalam Upacara Pernikahan Di Kecamatan Kajang Kabupaten Bulukumba yang dikaji berdasarkan pendekatan dari pemahaman yang ditulis oleh Suzanne K Langer terjemahan F.X Widaryanto dengan judul Problematika Seni, mengatakan bahwa symbol seni adalah sesuatu yang diciptakan oleh seniman secara konvensional digunakan bersama, teratur, dan benar-benar dipelajari, sehingga memberi pengertian hakikat karya seni, yaitu suatu kerangka yang penuh dengan makna untuk dikomunikasikan kepada orang lain, kepada lingkungannya, dan kepada dirinya sendiri, sekaligus sebagai produk dan ketergantungan dalam interaksi social. Maksudnya adalah bahwa dalam enelitian ini akan dikaji makna simbolik tari dan keterkaitannya dengan upacara pernikahan dalam masyarakat Kajang.

\section{Definisi Operasional Variabel}

Dalam pembahasan sebelumnya telah dikemukakan mengenai variable yang telah diteliti, oleh sebab itu untuk mempermudah tercapainya tujuan yang diharapkan pada penelitian ini maka perlu dijelaskan variablevariabel tersebut sebagai berikut:

a. Tari Pabbatte Passapu, merupakan tari yang khusus ditarikan oleh laki-laki. Tari ini awalnya berkembang dikawasan masyarakat Adat Tana Toa, namun sekarang sudah mulai ditarikan oleh sanggar-sanggar yang ada di luar kawasan adat tapi masih dalam lingkup Kecamatan Kajang. Tari ini memiliki struktur gerak yang unik karena digarap dengan teknik tradisional atau tanpa mempertimbangkan estetika barat.

b. Makna simbolik dimaksudkan adalah sesuatu yang diciptakan oleh seniman secara konvensional digunakan bersama, teratur, dan benar-benar dipelajari, sehingga memberi pengertian hakikat karya seni, yaitu suatu kerangka yang penuh dengan makna untuk dikomunikasikan kepada orang lain, kepada lingkungannya, dan kepada dirinya sendiri, sekaligus sebagai produk dan ketergantungan dalam interaksi social

c. keterkaitan, yang dimaksudkan adalah hubungan antara tari dan upacara itu sendiri, dalam hal ini dikaji dengan keterkaitan secara emosional. Maksudnya adalah melihat hubungan antara tari dengan upacara pernikahan berdasarkan makna yang melekat pada tari. 
Rahma M, Makna Simbolik Tari Pabitte Passapu Pada Upacara Pernikahan Di Kecamatan Kajang.

\section{HASIL DAN PEMBAHASAN \\ 1.Hasil \\ 1.1 Keterkaitan Tari Dengan Upacara}

Upacara pernikahan pada masyarakat Kajang merupakan suatu prosesi yang memiliki rangkaian panjang dalam persiapannya. Adapun rangkaian prosesi upacara pernikahan yang biasa digelar oleh masyarakat Kecamatan Kajang pada umumnya adalah sebagai berikut:

1. A'manu-manu (penjajakan)

2. Panai Doi (lamaran resmi)

3. Anrio bunting (siraman)

4. A'ba'ra (mapaccing)

5. Pa'bitte passapu (Pertunuan tari Pabitte passapu)

6. Panai Ribola (Proses menjelang ijab qabul)

7. Pantama Ribili (pengantin laki-laki masuk ke kamar penganti perempuan)

8. A'matoang (menemui mertua)

9. Angnganre bunting (memberi makan/menyuapi kedua mempelai)

10. Lampa basa (kunjungan ke pihaklakilaki)

11. Bangngi bisang (keluarga kedua mempelai saling berkunjung)

Pada pelaksanaan upacara pernikahan masyarakat Kajang dalam kawasan Tana Toa, Tari ini memiliki keterkaitan tersendiri dengan upacara pernikahan tersebut, yakni keterkaitan secara emosional. Dikatakan demikian sebab masyarakat Kajang sangat membanggakan tari ini sebagai salah satu budaya yang sangat mereka jaga dan menjadi ciri atau identitas mereka. Sebab ketika menyebut Kajang, orang luar pasti teringat akan tiga hal, yakni komunitas berbaju hitam, komunitas yang sangat ditakuti sekaligus dikagumi bahkan oleh masyarakat dunia karena kepercayaan dan culture hidup yang dibangun, serta akan menyebut Tari Pabbitte Passapu. Hal inilah yang menyebabkan jika masyarakat melaksanakan satu upacara rasanya tidak lengkap bila tidak menggelar atau mempertunjukan tari pa'bitte passapu, bahkan kebiasaan ini bukan saja menjadi kebiasaan bagi masyarakat Kajang
Dalam tetapi juga masyarakat Kajang Luar, bahkan daerah lain yang masih termasuk dalam wilayah Bulukumba Timur.

Pabbitte Passapu pada upacara pernikahan menjadi magnet tersendiri yang bisa mendatangkan dan menarik minat banyak orang baik dari kalangan masyarakat Kajang dalam (kawasan adat) maupun Kajang luar untuk hadir pada pernikahan yang digelar oleh salah satu penduduk Kajang. Hal ini disebabkan karena emosi kedaerahan yang masih sangat kental dalam hati mereka, dan tari ini menjadi salah satu 'hal' yang sangat mampu menumbuhkan dan menggelorakan rasa itu. Bagi masyarakat Kajang ada uforia tersendiri dan harapan yang besar bahwa acara akan berjalan lancar dan meriah jika menggelar tari tersebut, meskipun tari ini tidak memiliki makna tersediri baik dari gerak maupun dari kostum yang digunakan terhadap ritual pernikahan itu sendiri. Hanya saja karena rasa memiliki yang begitu kuat pada tari ini sehingga jika digelar pada upacara pernikahan biasanya diselipkan doa bagi mempelai dari syair yang dinyanyikan oleh penari pada saat menarikan tari ini sehari sebelum proses ijab qabul dilaksanakan bagi masyarakat Kajang dalam, dan saat ini sudah dilaksanakan pada saat siang hari oleh masyarakat Kajang luar.

Terjadinya perbedaan waktu bagi masyarakat Kajang dalam dan Kajang luar, disebabkan pada pelaksanaan upacara pernikahan bagi masyarakat Kajang Dalam, kehadiran kepala suku yakni Ammatoa beserta seluruh pemangku adat sangat penting, sehingga tari ini dipergelarkan pada saat malam hari, tepatnya pada saat Ammatoa dan pemangku-pemangku adat yang lain telah datang untuk acara angnganre ada' pada saat ritual A'ba'ra dilaksanakan, selain itu bagi masyarakat Kajang Dalam ritual A'bara ini juga merupakan acara yang sama pentingnya dengan prosesi ijab qabul, sebab pada ritual ini calon mempelai perempuan betul-betul dipersiapkan (di doakan) untuk menghadapi kehidupan selanjutnya. Ritual A'bara 
(mappaccing) yang berarti mensucikan atau membersihkan diri bermakna bahwa mulai malam tersebut calon mempelai wanita akan membersihkan diri dari sifat yang kurang baik, sifat kekanak-kanakan menjadi perempuan yang siap memikul tugas sebagai istri dan calon ibu bagi anak-anaknya kelak, melupakan semua masa lalunya dan bersiap menghadapi masa depan hanya bersama dengan suaminya, dengan restu dan doa dari kedua orang tua dan seluruh pemangku adat yang hadir.

Acara Angnganre ada' ini memang khusus dilaksanakan untuk menjamu para pemangku adat, dan tari ini berfungsi hiburan yang diperuntukkan untuk menghibur para pemangku adat tersebut. Sedang bagi masyarakat Kajang luar tari ini biasanya difungsikan sebagai tari penjemputan bagi calon mempelai laki-laki dan keluarga besarnya. Dan biasanya, doa dan pengharapan juga dititipkan pada syair yang mengiringi tari ini, agar sang calon mempelai dapat melaksanakan ijab qabul dengan baik dan lancar, serta siap menghadapi kehidupan selanjutnya dan bertanggung jawab sebagai kepala keluarga. Namun disisi lain, selain pemaknaan yang terdapat pada tari tersebut, saat ini sesungguhnya tari pa'bitte passapu yang hadir hampir pada semua ritul-ritual suka cita masyarakat baik pada masyarakat Kajang Dalam maupun Kajang Luar, juga menjadi hiburan tersendiri bagi masyarakat mengingat diwilayah Kecamatan Kajang tidak ada tari lain yang ada dan berkembang selain tari ini, dan tari ini juga menjadi prestise tersendiri bagi masyarakat yang mampu menghadirkan pada ritual-ritual yang digelar.

\subsection{Makna simbolik (Tanda dan petanda) Pada Pertunjukan Tari Pabitte Passapu}

Seperti telah dibahas diatas bahwa tari ini tidak memiliki makna secara langsung dengan tari ini, hanya saja karena kedekatan secara emosional yang begitu dengan dengan masyarakat sehingga hampir dalam semua upacara yang sifatnya suka cita tari ini selalu dihadirkan, tidak terkecuali pada pacara pernikahan masyarakat Kajang. Sehingga untuk memaknai tidak dapat dilakukan seperti umumnya jika memaknai sebuah tari. Sebab tari ini tidak memiliki makna yang terkait secara langsung dengan upacara pernikahan dari bentuk penyajian ragam peragam secara khusus. Namun, ketika tari ini ditarikan justru menjadi tanda dan petanda tersediri, seperti tergambar pada tabel dibawah ini:

\begin{tabular}{|c|c|c|}
\hline No & Tanda & Petanda \\
\hline 1 & $\begin{array}{l}\text { bahwa } \\
\text { seluruh } \\
\text { pemangku } \\
\text { adat telah } \\
\text { hadir di } \\
\text { rumah } \\
\text { mempelai } \\
\text { perempuan } \\
\text { ataupun } \\
\text { laki-laki. }\end{array}$ & $\begin{array}{l}\text { Seperti umumnya sebuah } \\
\text { upacara pernikahan, } \\
\text { malam sebelum proses } \\
\text { ijab qabul dilaksanakan } \\
\text { biasanya banyak } \\
\text { rangkaian kegiatan yang } \\
\text { dilaksanakan dan } \\
\text { merupakan adat istiadat } \\
\text { yang telah dijalani secara } \\
\text { turun temurun dan masih } \\
\text { berlaku hingga kini } \\
\text { diantaranya adalah ritual } \\
\text { a'ba'ra. Dan ritual ini } \\
\text { menjadi salah satu } \\
\text { moment sakral bagi calon } \\
\text { mempelai dan } \\
\text { keluarganya sehingga } \\
\text { pada moment ini } \\
\text { diharapkan semuan } \\
\text { pemangku adat hadir } \\
\text { untuk memberikan doa } \\
\text { restu kepada calon } \\
\text { mempelai agar siap } \\
\text { menghadapi prosesi ijab } \\
\text { qabul dan yang terpenting } \\
\text { siap menghadapi } \\
\text { kehidupan barunya. Dan } \\
\text { bagi masyarakat Kajang } \\
\text { Dalam, begitu tari ini } \\
\text { mulai ditarikan berarti } \\
\text { seluruh pemangku adat } \\
\text { telah hadir dilokasi acara. }\end{array}$ \\
\hline 2 & $\begin{array}{l}\text { Rangkaian } \\
\text { Prosesi } \\
\text { upacara } \\
\text { pernikahan } \\
\text { akan } \\
\text { dimulai }\end{array}$ & $\begin{array}{l}\text { Pada sebuah upacara } \\
\text { pernikahan kehadiran tari } \\
\text { pa'bitte passappu } \\
\text { memiliki arti tersendiri } \\
\text { bagi amasyarakat Kajang } \\
\text { Dalam, begitu tari ini } \\
\text { ditarikan, itu merupakan } \\
\text { pertanda bahwa }\end{array}$ \\
\hline
\end{tabular}


Rahma M, Makna Simbolik Tari Pabitte Passapu Pada Upacara Pernikahan Di Kecamatan Kajang.

\begin{tabular}{|c|c|c|}
\hline & & $\begin{array}{l}\text { rangkaian ritual } \\
\text { perkawinan, yakni ritual } \\
\text { A'ba'ra (mapaccing) } \\
\text { akan dimulai karena } \\
\text { begitu tari ini mulai } \\
\text { ditarikan berarti sebuah } \\
\text { prosesi penting akan } \\
\text { segera dilaksanakan dan } \\
\text { ini biasanya akan } \\
\text { memunculkan perasaan } \\
\text { takjub tersendiri bagi } \\
\text { masyarakat, selain } \\
\text { perasaan takjub juga } \\
\text { muncul rasa antusias, } \\
\text { haru, serta suka cita } \\
\text { tersendiri dalam hati } \\
\text { keluarga besar mempelai } \\
\text { dan masyarakat yang } \\
\text { terlibat dalam prosesi } \\
\text { tersebut. Sedang bagi } \\
\text { Masyarakat Kajang Luar, } \\
\text { karena tari ini ditarikan } \\
\text { pada saat siang hari } \\
\text { menjelang akad nikah } \\
\text { dilaksanakan, maka } \\
\text { begitu tari ini mulai } \\
\text { ditarikan pertanda bahwa } \\
\text { calon mempelai laki-laki } \\
\text { telah tiba dikediaman } \\
\text { calon mempelai } \\
\text { perempuan dan rangkaian } \\
\text { prosesi akad nikah akan } \\
\text { segera dilaksanakan. }\end{array}$ \\
\hline 3 & $\begin{array}{l}\text { Prestise } \\
\text { bagi } \\
\text { masyarakat }\end{array}$ & $\begin{array}{l}\text { bagi masyarakat Kajang, } \\
\text { menghadirkan tari ini } \\
\text { pada upacara pernikahan } \\
\text { selain mengikuti tradisi } \\
\text { yang telah ada, juga } \\
\text { merupakan prestise } \\
\text { tersendiri bagi } \\
\text { masyarakat Kajang luar } \\
\text { yang menghadirkannya } \\
\text { pada upacara-upacara } \\
\text { atau ritual-ritual yang } \\
\text { dilaksanakan, diantaranya } \\
\text { memberi kesan bahwa } \\
\text { yang memiliki hajat } \\
\text { adalah bangsawan atau } \\
\text { memiliki strata social } \\
\text { tinggi, dan mampu secara } \\
\text { ekonomi. Sebab untuk } \\
\text { menghadirkan tari ini } \\
\text { membutuhkan budget }\end{array}$ \\
\hline
\end{tabular}

\begin{tabular}{|l|l|}
\hline & $\begin{array}{l}\text { tersendiri terlebih pada } \\
\text { setiap penampilannya, } \\
\text { personil tari ini terbilang } \\
\text { banyak. Biasanya pada } \\
\text { satu pertunjukan penari } \\
\text { berjumlah kisaran 8-12 } \\
\text { orang dengan 3 sampai 4 } \\
\text { orang pengiring, hal } \\
\text { inilah yang menyebabkan } \\
\text { bagi yang menghadirkan } \\
\text { tari ini pada kegiatan- } \\
\text { kegiatan atau acara-acara } \\
\text { di kediamannya dianggap } \\
\text { memiliki kemampuan } \\
\text { secara finansial yang } \\
\text { lebih. }\end{array}$ \\
\hline
\end{tabular}

\section{Pembahasan}

Pada sebuah upacara pernikahan biasanya segala hal yang dihadirkan pada setiap tahapan kegiatan memiliki makna tersendiri yang terkait dengan filosofi masyarakat dan terhadap prosesi pernikahan itu sendiri. Demikian juga halnya bagi masyarakat Kajang yang berdiam dalam kawasan adat yang lebih dikenal dengan sebutan Kajang Dalam ataupun masyarakat yang bermukim diluar kawasan tapi masih dalam wilayah Kecamatan Kajang yang disebut Kajang Luar, prosesi atau upacara pernikahan adalah sesuatu yang sangat penting dan memerlukan persiapan yang panjang, mulai dari memastikan kesediaan dari calon mempelai hingga proses pelaksanaannya.

Tari Pabitte Passapu, meskipun secara khusus tidak memiliki makna yang terkait secara langsung dengan upacara pernikahan, ataupun dengan upacara-upacara lainnya mengingat tari ini terinspirasi dari kebiasaan masyarakat Kajang menyabung ayam jika ada waktu senggang atau ketika mereka penat dengan segala aktivitas, mereka menyabung ayam untuk menghibur diri sekaligus sebagai ajang sosialisasi antar warga. Dan tanpa diketahui siapa sebenarnya pencipta tari ini, walau menurut penuturan dari beberapa warga dan pelaku tari, ada yang mengatakan bahwa tari ini diciptakan 
oleh Karaeng Kajang dan sekarang menjadi satu-satunya warisan dalam bentuk tari untuk masyarakat Kajang. Oleh sebab itu masyarakat Kajang sangat menjaga tari ini dari kepunahan dengan meregenerasikan kepada penerus-penerus mereka. Dan karena 'kedekatan' masyarakat Kajang dengan tari ini begitu kuat sehingga pada setiap kegiatan-kegiatan atau upacara-upacara adat yang mereka gelar tari ini diusahakan menjadi bagian dari upacara tersebut. Dan, selain tari ini ada juga bentuk seni lain yang berkembang yakni, angnganro (angngaru'), bahkan saat ini keduanya sering dijumpai hadir bersamaan.

Pada setiap geraknya tari ini, memiliki makna bahwa masyarakat Kajang sangat patuh pada pemimpinnya dan sangat menghormati orang lain, serta menujukkan bahwa selain menguasai ilmu tentang hakikat kehidupan mereka juga menguasai hal-hal yang bersifat 'kehakikian', bahkan masyarakat dalam kawasan di kenal sangat dekat denga hal-hal mistis dan magis, namun tidak menjadikan mereka sombong akan kemampuan yang mereka miliki dan tetap memiliki rasa belas kasih kepada siapa saja, baik kawan maupun lawan terlebih kepada orang yang sudah tidak berdaya, masyarakat Kajang memang dikenal dengan budaya hidup kekeluargaan dan gotong royong yang masih sangat kental.

Selain nilai yang terdapat dalam gerak, nilai yang sarat akan makna juga terdapat pada pakaian yang dikenakan sehari-hari, yang juga sekaligus merupakan kostum yang dikenakan saat menarikan tari Pabitte Passapu, bagi masyarakat Kajang hitam memberi arti dan makna tersendiri bagi masyarakat, Karena menurut masyarakat Kajang warna hitam merupakan rambu-rambu mereka dalam bersikap, berperilaku dalam hidup ini karena dengan mengenakan warna hitam mereka akan selalu ingat bahwa setelah kehidupan yang terang benderang dan gemerlap ini akan ada saatnya kita akan hanya melihat kegelapan saja yakni ketika berada didalam kubur, selain itu warna hitam juga merupakan warna netral yang bisa dipadukan dengan warna dan bentuk apa saja, dan warna hitam juga tidak cepat kelihatan kotor meskipun di pakai berhari-hari, mengingat diwilayah Kajang khususnya dalam kawasan adat mata air untuk keperluan sehari tidak banyak, hanya terdapat dua sumur dalam kawasan satu sumur khusus untuk digunakan untuk keperluan memasak dan satu sumur lagi untuk keperluan mandi, mencuci, dll. Selain itu, hitam juga memiliki makna yang menunjukkan kesederhanaan, elegan, dan mistis.

\section{SIMPULAN DAN SARAN \\ A. Kesimpulan}

Makna simbolik tari adalah suatu usaha untuk menemukan symbol-simbol yang terdapat dalam sebuah pertunjukan tari, dan symbol-simbol tersebut tidak akan berarti apa-apa jika tidak dimaknai. Dalam sebuah tari pemaknaan ini dianggap penting untuk memudahkan memahami sebuah tari sehingga pada waktu menarikan tari akan tepat dari sisi ekspresi. Terlebih jika pemaknaan tari tersebut terkait dengan konteks acara atau upacara tertentu. Dan pada tari Pabbitte Passapu pada dasarnya secara khusus tari ini tidak terkait langsung dengan prosesi pernikahan tersebut, hanya saja tari ini memiliki ikatan secara emosional dengan masyarakat sehingga kehadiran tari ini menjadi begitu penting pada setiap upacara-upacara suka cita masyarakat Kecamatan Kajang.

\section{B. Saran}

Berdasarkan kesimpulan tersebut diatas, maka dapat disarankan beberapa hal sebagai berikut:

1. Agar mahasiswa dapat terlatih untuk terus mengasah kemampuan dalam hal pemaknaan tari secara simbolik, sehingga dengan sendirinya memperoleh kesadaran menari dengan rasa, teknik yang betul dan baik.

2. Diharapkan dapat menjadi pertimbangan bagi pelaku tari dalam usaha menumbuhkan kesadaran untuk memahami dan mempelajari tari secara 
Rahma M, Makna Simbolik Tari Pabitte Passapu Pada Upacara Pernikahan Di Kecamatan Kajang.

baik dengan teknik benar, serta menumbuhkan keinginan untuk mempelajari dan menganalisis tari-tari tradisional lainnya, serta menghargai keberadaan sebuah tari sebagai bagian dari budaya manusia.

3. Diharapkan menjadi inspirasi untuk melakukan pencatatan tari sehingga taritari tradisional kita dapat terdokumentasikan dengan baik.

\section{DAFTAR RUJUKAN}

Astini, Dewi, 2007, Bedha Jurnal Surya Seni Penciptaan dan Pengkajian Seni ISI Yogyakarta, Yogyakarta

Goffman dalam Murgiyanto, Sal, 2015, Pertunjukan Budaya Dan Akal Sehat, Jakarta; FSP-IKJ

Hawkins, Alma W, 2003, Terj. Hadi, Mencipta Lewat Tari, Yogyakarta: Manthili

Hadi, Sumadiyo Y, 2011, Koreografi Bentuk-Teknik-Isi, Yogyakarta; Multi Grafindo

Langer, Zusanne K, Terjemahan FX. Widaryanto, 2006, Problematika Seni, Bandung; Sunan Ambu Press

Murgiyanto, Sal, 2004, Tradisi dan Inovasi Beberapa Masalah Tari Di Indonesia, Jakarta; Wedatamawidya Sastra

-----------, 2015, Pertunjukan Budaya dan Akal Sehat, Jakarta; Penerbit Fak. Seni Pertunjukan IKJ.

Peursen, Van C.A, 1988, Strategi Kebudayaan terjemahan dari buku Cultuur In Stroomversnelling oleh Dick Hartoko, Yogyakarta; Kanisius

Soedarsono, 1986, Elemen-Elemen Dasar Komposisi Tari Terj. Dari Buku Dances Composition The Basic Elemen oleh La Mery, ISI Yogyakarta: Lagaligo

Wahyudianto, 2009, Wajah Tari dalam Perspektif, Surakarta: ISI Perss Surakarta 